\title{
Selecting Green Suppliers with Analytic Hierarchy Process for Biotechnology Industry
}

\author{
Shui-Shun Lin \\ Department of Business Administration \\ National Chin-Yi University of Technology \\ Taichung, Taiwan, ROC \\ E-mail: sslin@ncut.edu.tw \\ Ying-Shen Juang \\ Department of Business Administration \\ Chung-Hua University, Taiwan, ROC.
}

\begin{abstract}
The biotechnology industry is recognized as one of the industries of the $21^{\text {st }}$ century with the most potential. The Taiwanese government accordingly has included the biotechnology industry as part of the project entitled "TwoTrillion-Twin-Stars". Under current environmental protection regulations, the pressures related to the green industrial revolution are being intensified. Enterprises collaboratively executing green supply chain management with suppliers are urgently needed. One crucial step of supply chain management is to select appropriate partners. Green supplier selection is conducted by embedding the environmental protection concept within supplier evaluation processes. The primary intention of this study is to investigate the selection process for green suppliers in the biotechnology industry via utilization of the analytic hierarchy process (AHP). The research study collaboratively establishes a set of green supplier evaluation criteria and designs the evaluation processes. In short, the objectives are twofold: (1) to establish collaborative evaluation criteria of green suppliers utilizing AHP; and (2) to construct evaluation processes according to the aforementioned set of criteria. The findings of this research suggest that the major concerns in terms of green supplier selection for biotechnology companies are currently cGMP certification, established environmental policies, and product acknowledgement. Also, an evaluation form consisting of green criteria and weights is constructed to facilitate the selection process.
\end{abstract}

Keywords: Green supply chain, Green supplier selection, Analytic Hierarchy Process, Biotechnology industry

\section{Introduction}

In recent years, the hi-tech industry has been greatly supported by governments, and a great deal of talent and funds have been absorbed into several relative fields. John Naisbitt (1990) pointed out in Megatrends 2000 that the biotechnology revolution was one of ten trends that influenced peoples' lives in the 1990s. The biotechnology industry is a kind of sunrise industry, as it requires relatively low energy consumption and high knowledge intension, and offers high added value. According to a forecasting report of the Industrial Economics and Knowledge Center at the Industrial Technology and Research Institute (ITRI), the global biotech market grows at $18 \%$ per annum on average. According to forecast of the Industrial Development Bureau at the Ministry of Economic Affairs, biotechnology annual output in Taiwan would amount to $\$ 3$ billion USD, equivalent to NT $\$ 108.2$ billion. Thus, the Taiwanese 
government included it in the "Two-Trillion-TwinStars" project as a national key developing industry in 2002, and has invested NT\$150 billion since then to boost the Taiwanese biotechnology industry (MOEA, 2006). In the next five years, the biotechnology industry turnover is expected to grow at $25 \%$ per annum on average, driving a NT $\$ 150$ billion investment. Further, over 500 biotechnology companies will have been founded during this tenyear period (MOEA, 2006). However, the issue of environmental protection gradually becomes important for biotechnology companies, in terms of new product $R \& D$ and manufacturing processes, especially the impacts of water and air pollution (Shief, 2006).

Supporting enterprises with technology needed for green supply chains is one way to raise industry competence. With the looming of a green industry revolution, enterprises must be environmentalfriendly, and must collaborate with both upstream and downstream supply chain partners. Green supply chain management (GSCM) was first proposed in 1970s. However, scholars and entrepreneurs plunge into its study until 1990s. The concept of GCSM can be simply defined as: an enterprise that collaborates with suppliers to improve products or manufacturing processes so as to raise environmental performances of suppliers and customers (MOEA, 2006).

Since 1999, many theoretical studies and practical cases on green supply chain management in Europe and the US have appeared. One key reason that green supply chain management has become a worldwide phenomenon is that consumers, investors and governments have all become more concerned about environmental protection work. Amongst globalization trends, all large-scale manufacturers have integrated upstream and downstream supply chains one after the other in order to achieve costsaving in an efficient way. Relationships between supplier and manufacturer are no longer traditionally hostile battles, but have evolved into partner relationships (Lin, 2002). Cooperation with fewer suppliers can ensure a high quality yet low cost supply source; therefore, supplier selection has become more important. In terms of the green supply chain issue, green information and communication systems, environment quality management systems, green product design management, and green supply chain audits are all linked to each other. Therefore, some
European Union (EU) countries have begun to focus on cross-link relationships regarding supply chains, and have transformed everlasting environmental protection demands to activate legislation aimed at encouraging involvement of all interested parties (including final consumers) through a market guided system to extend producer responsibility.

The choice of an appropriate cooperative partner is at the heart of supply chain management, and material or product/service providers are the most closely associated with an enterprise. If we can find a supplier that complies with industry characteristics and meets supply chain requirements, then supply chain competence can be enhanced; on the contrary, adding improper suppliers to the supply chain disables the collaborative operation of the whole supply chain, which either causes delays in terms of delivery and production planning, or causes credit and financial losses. Therefore, evaluation of appropriate suppliers is a basic step in terms of supply chain management. In the existing literature, the supplier evaluation for biotech industry was seldom discussed. In practice, efficient supplier evaluation operations are difficult to perform in the biotechnology industry and a set of evaluation systems need to be built that consider the concept of environmental protection. In this study, we derive green supplier evaluation criteria and develop an evaluation model for biotechnology industry to overcome abovementioned difficulties.

The objective of this study is to develop a green supplier evaluation model for the biotechnology industry. Specifically, the objective is twofold: (1) to establish collaborative evaluation criteria of green suppliers utilizing AHP; and (2) to construct evaluation processes according to the set of aforementioned criteria. Based on industry interviews, this study analyzes how manufacturers perform green supplier evaluations, and further design an evaluation form with standard evaluation procedure. Based on the related literature, we investigate the green criteria required by a company during green supplier evaluation, which helps us understand how to build a green evaluation criterion structure and supplier evaluation model. Finally, when building the supplier evaluation criterion structure, we build evaluation criteria into a systematic hierarchy structure with the help of AHP. 


\section{Literature Review}

\subsection{Green Supply Chain Management}

Supply chain management refers to utilizing, from the upfront supplier to the end consumer, a series of efficient operations to integrate product-related material planning and control, based on the interests of all members in the channel including suppliers, manufacturers, warehouses and retailers. By increasing customer service levels with management skills, existing resources can be fully used and whole system costs can be minimized (Chen \& Chen, 2001). The objective of supply chain management is to integrate markets, distribution networks, manufacturing processes and purchasing events in all nodes of the whole supply chain, to realize high level yet low cost customer service, and thereby enlarge competitive advantages. Supply chains expand the original logistic system by not only extending conventional vertical integrated logistics, but also by surpassing logistics through taking full account of the whole logistic process and various environmental factors affecting the process (Juang et al., 2006).

Webb (1994) pointed out that product manufacturing had to use environmental criteria to choose appropriate raw materials, and had to pay attention to recycling and the green purchasing concept as well. Beamon (1999) suggested that environmental factor must be introduced to the supply chain model to put forward wider supply chain design methods. The green supply chain generally refers to supplier product and environmentally related management, or to incorporating environmental protection principles into supplier management systems, the purpose of which is to enhance market competence by implanting more environmental protection concepts. In practice, some companies propose environmentspecific purchasing schemes, as well as performance or evaluation processes, to make all or most suppliers follow, while other companies list types of environmentally hazardous substances, and require that no substance on the list exist within materials or components.

Kuo et al. (2004) indicated that, in the whole process of supply chain management, the combination of the process, the products, the packaging, and the distribution have to take environmental problems into account, not only by reducing the social burden on the environment, but also by meeting environmental laws, and lowering green trading barriers. Lai (2004) suggested that building green supply chains has become a major challenge, but that the trend of providing green products can allow us to advance towards a sustainable society. Further, component or material suppliers must consider environmental protection related system besides existing management system; in other words, they must propel green supply chain management methods.

\subsection{Supplier Evaluation Methods}

In traditional buyer and supplier relationships, each party protects itself, and rarely considers using close cooperation to achieve higher profits. As a result, both buyers and suppliers compete for price advantages in transactions, in order to have the lowest production cost. Their associations are mostly in terms of short-term contracts. Such a price-driven philosophy leads to limited communication between buyers and sellers during transactions, and only rare instances of sharing technical information (Spekman, 1998). In fact, often bilateral hostile relationships are the result due to less trust among manufacturers. Stuart \& McCutcheon (1995) discussed building buyer-and-supplier relationships in one conceptually empirical investigation. Newman (1989) and Rubin \& Cater (1990) pointed out that, in contrast to short-term contracts, bilateral relationships between buyers and suppliers allow both parties to move closer under a long-term strategic coalition. Blenkhorn \& Noori (1991) and McCutcheon et al. (1997) suggested that good cooperation between buyers and suppliers leads to more rapid information exchange, which in turn generates greater environmental adaptivity and flexibility for organizations. All of the above literature stresses successful buyer-and-supplier relationships, and key factors pertaining to collaborative trading relationships.

Choosing appropriate collaborative partners is the most important step for supply chain management, while materials or service providers are the most closely associated with the enterprise. Finding suppliers that comply with industry characteristics and can satisfy the supply chain demand enhances supply chain competence 
Table 1. Studies of Supplier Evaluation and Methods

\begin{tabular}{|c|l|}
\hline Method & \multicolumn{1}{|c|}{ References } \\
\hline Weighted Linear Model & Wind \& Robinson (1968), Lamberson et \\
Gl. (1976), Timmerman (1986) \\
Minkle et al. (1969) \\
Matrix Model & Gregory (1986) \\
Linear Programming & Turner (1988), Pan (1989), Ross (2001) \\
Multi-objective Programming & Muralidharan (2002), Wang (2004) \\
Mixed Integer Programming & Kumar (2004) \\
Cost of Ownership Analysis & Ellram (1995), Degraeve (2000), Bhutta \\
& (2002), Crama (2004) \\
Judgmental Model & Patton (1996) \\
Principal Component Analysis & Petroni \& Braglia (2000) \\
Interpretive Structural Model & Mandal \& Deshmukh (1994) \\
Statistical Analysis & Mummalaneni et al. (1996), Muralidharan \\
& (2001) \\
Neural Network & Siying et al. (1997) \\
Extenics System & Su and Zhang (2001) \\
Data EnvelopmentAnalysis & Weber and Desai (1996), Weber (1998), \\
& Narasimhan (2001), Talluri et al.(2005), \\
Analytic Hierarchy Process & Narasimhan (1983), Nydick \& Hill (1992), \\
& Mohanty \& Deshmukh (1993), \\
Barbarosoglu \& Yazgac (1997), \\
Ghodsypour (1998), Chien(2000), Bhutta \\
Environmental Impact Evaluation & (2002), Sarkis (2002) \\
& Buckley (1985), Lee(2002), Lai(2004) \\
Lun et al. (2003), Rodrigues et al. (2003), \\
Liu \& Hai (2005) \\
Voting Analytic Hierarchy Process \\
Criteria Confirmation Analysis & McCutcheon \& Hartley (1997), Wang \\
& (2004) \\
Collaborative Planning & Prahinski (2004), Fu (2004) \\
Geier \& Kopke (1998), Scharnhorst et al. \\
(2005) Evaluation
\end{tabular}

(Bharadwaj, 2004; Chien, 2000; Liu \& Hai, 2005). However, adding improper suppliers to the supply chain disables collaborative operations of the whole supply chain, either delaying deliveries and production plans, or causing credit and financial losses. Thus, appropriate supplier evaluations are the most fundamental step to supply chain management.

A wide variety of supplier evaluation methods have been used, including linear programming, multi-objective programming, data envelopment analysis, AHP and fuzzy AHP, etc. Table 1 shows studies pertaining to supplier evaluation methods as well as some literature sources.

\subsection{Green Supplier Evaluation}

Noci (1997) built a conceptual green supplier evaluation procedure, and summarized environmental protection related issues in the past decade as: (1) manager recommended programs to reduce air irradiation, solid waste, wastewater, and energy loss in terminal pipeline planning; (2) use of environmental protection technology in manufacturing processes to reduce their influence on natural resources; (3) changing operation processes and ecology plan structures in terms of products and service. The study proposed three stages of green supplier evaluation: (1) to acknowledge related stipulations of environmental protection regulations; (2) to acknowledge expected contributions of varied suppliers in terms of each objective; and (3) to formulate a final supplier evaluation process. Goffin et al. (1997) pointed out that previous supplier selection concentrated on issues regarding price, quality and delivery speed. However, in the current global supply chain environment, evaluating supplier requirements has become more encompassing, as strategic considerations including technical expertise, financial capability and aftersale service must also be taken into consideration. Coupled with the execution of some international environmental protection decrees, OEM dominant Taiwanese manufacturers must inevitably take account of environmental protection related regulations during supplier evaluations in order to meet international market demands.

Handfield et al. (2002) indicated that purchasing managers of modern enterprises often consider whether or not suppliers comply with environmental protection related laws and regulations when buying materials or products. The ten easiest and most important environmental protection criteria in purchasing decisions were put forward as a reference for purchasing managers, and three cases were provided that concern AHP. Humphreysa et al. (2003) argued to add environment factors in supplier evaluations, so as to respond effectively to the pressure of environmental protection. In order to help enterprises select green suppliers, a set of Case-Based Reasoning (CBR) means was proposed to build a knowledge system including qualitative and quantitative criteria, and thereby help to select the optimum green supplier. This system allowed enterprise managers to shorten evaluation times, and greatly improved overall decision efficiency. Lai (2004) discussed the topic of green supplier management within the electronics industry, and employing the multi-criteria decision method as the basis of supplier evaluation, established a set of sequential evaluation procedures to facilitate OEM data collection, rating 
and scoring, as well as adjusted decision weights. Examples of printed circuit board (PCB) purchasing and supply were provided to build a real evaluation model. Tsai (2005) suggested that under WEEE and RoHS regulations, the electronics industry had to break away from past quality-based product specifications, and add environmental protection requirements. Some packagers have begun to establish green supply chains and green purchasing standards to adapt to market demands. The most important part of the supply chain was the evaluation of qualified suppliers. According to green purchasing requirements, the supplier evaluation criteria must be modified. Chang (2005) interviewed manufacturers, and all interviewees regarded the selection of green suppliers as a way to collaborate with international big firms and compete for steady or increasing orders. His study combined expert experience and knowledge, formulated criteria of selecting green suppliers, and provided a scoring criteria of green suppliers for the flexible printed circuit (FPC) industry, so that manufacturers could select appropriate green FPC suppliers. It also provided a reference for the industry, and aided enterprises in finding a profit balance between the environment and company economics.

Handfield et al. (2002) stated that, amid the intensifying pressure of environmental protection, environmental protection criteria had to be taken into account during supplier evaluations. Hence, according to comments made by those who make enterprise decisions and environment experts, the performance indices related to evaluating suppliers were listed, and the easiest and most important evaluation indices for enterprises to evaluate suppliers were highlighted. As environmental protection pressure continues to rise, quality and price are no longer competitive weapons in terms of supplier evaluation, as the most important element is currently not hampering either the environment or consumers. Therefore, evaluation indices have been transformed from earlier quality-based ones to a green-based one that pays special attention to environmental protection. In Taiwan, small-andmedium sized enterprises are the majority, accounting for $97.80 \%$ of total enterprises (MOEA, 2006). Under RoHS and WEEE, members of a supply chain system must purchase raw materials that minimally pollute the environment or acquire related environmental protection certification, and suppliers are mandated to supply products compliant with EU directives, or face losing opportunities in the global arena.

\section{Research Methodology}

This study mainly adopted AHP to analyze the importance of various green supplier evaluation criteria. Thus, related criteria were initially acquired from the related literature, and confirmed by expert interviews. We interviewed biotechnology managers to obtain the reference model for biotechnology manufacturers when evaluating green suppliers. A preliminary questionnaire was made after collecting and processing the literature, followed by discussion with biotechnology manufacturing professionals. The processes included asking experts to rate and score the criteria. Criterion unanimously regarded as important were included, while less important ones were omitted.

AHP is a multi-attribute evaluation method developed in 1971 by Prof. Thomas L. Saaty of Pittsburg University, and it is primarily used to solve decision problems in uncertain situations and with multiple evaluation criteria. Combined with expert discussion, the AHP hierarchy structure can be generated from confirmed criteria. To avoid excessive industry discrepancies between the experts, all experts chosen for this study were senior executives of purchasing or environment engineering departments within the industry. This study included five such experts, who were all senior executives of listed or over-the-counter pharmaceutical firms with years of industry experience, and who all had unique viewpoints on subject of this study. Eisenhardt (1989) pointed out that, when conducting a case study, the case number should normally be between four and ten, as fewer cases hamper theory construction, and more cases become hard to analyze due to the relatively large amount of data. Therefore, this study included senior executives of five firms as interview subjects.

The above procedure can be shown as follows: (1) obtain criteria from literature, and filter them by expert interview to form AHP hierarchy structure; (2) design AHP questionnaire and assess comparative values; (3) compute weight of each criterion, and construct evaluation form as well as operational process. 


\section{Results and Discussion}

\subsection{Step 1: Extract Green Evaluation Criteria}

After the literature analysis, 24 criteria were induced and tabulated as shown in Table 2. However, to investigate the essential green criteria that significantly affect the evaluation of pharmaceutical product suppliers, in-depth interviews were also performed.

Pharmaceutical products are mainly for human and animal use, and there is high demand for product quality and dose accuracy. In circumstances related to the rising environmental protection pressure, supplier selection must be especially cautious. We chose to focus on the pharmaceutical

Table 2. Criteria Summary

\begin{tabular}{|c|c|c|}
\hline No. & Criterion & Description \\
\hline 1 & Environmental protection policy and objective & $\begin{array}{l}\text { Formulate environmental protection related policies or plan "product environment quality assurance" and } \\
\text { regulation restricted product environment quality objectives }\end{array}$ \\
\hline 2 & Environmental protection certification & Introduce or acquire environment management system certification (e.g.: IS0 14001, ROHS) \\
\hline 3 & Information transmission and exchange & $\begin{array}{l}\text { Summarize customer environment quality requirements and circulate to business departments, design and } \\
\text { technical departments and manufacturing departments }\end{array}$ \\
\hline 4 & Education and training & Draft environment related education and training courses with plans and implementations \\
\hline 5 & Environmental protection partner & Formulate and execute environmental protection related criteria along with supply chain members \\
\hline 6 & Executive support & Company management support implementation of environmental protection strategy \\
\hline 7 & Recycle and reuse & $\begin{array}{l}\text { Product R\&D consider reusability (material alternatives, decomposable, dividable), and check hazardous } \\
\text { substances, if any, for recycling }\end{array}$ \\
\hline 8 & Remanufacturing & Design of recyclable containers, reconstruction, remanufacture \\
\hline 9 & Green package & $\begin{array}{l}\text { Product package design (e.g., reusable package, high recovery package) complying with recycle } \\
\text { requirements }\end{array}$ \\
\hline 10 & Material alterability & Improve material labeling, reduce material types, use similar and compatible materials \\
\hline 11 & Green technical capability & Develop alternative materials, products, equipment and methods that alleviate life cycle shocks \\
\hline 12 & Usage of environmental-friendly material & $\begin{array}{l}\text { Whether or not supplier members use process banned substances in processing and has efficient control } \\
\text { of chemical substance data }\end{array}$ \\
\hline 13 & Ability of decreasing pollution & Whether or not product contains waste/toxic chemicals \\
\hline 14 & Recycled product treatment capability & Whether or not company is capable of treating recycled products \\
\hline 15 & Product acknowledgement & Whether or not customers trust and acknowledge product after purchase \\
\hline 16 & Environmental protection mark & Whether or not product design and package have honor of environmental protection mark \\
\hline 17 & Customer satisfaction & Whether or not environment management substances are summarized as per customer requirement \\
\hline 18 & Procurement of environmental-friendly material & Supplier purchase of material must comply with environmental friendly requirements \\
\hline 19 & Acquiring new environmental-friendly technology & Supplier manufacturing process must use new environmental-friendly technology \\
\hline 20 & Product redesign cost & List product redesign cost \\
\hline 21 & Employee training cost & List staff training cost \\
\hline 22 & Management of departmental document & $\begin{array}{l}\text { As per "product environment quality assurance system", outline documents and data to be managed by } \\
\text { various departments }\end{array}$ \\
\hline 23 & Bill of waste management & Manage various kinds of bills (e.g., chemical bill, laboratory and office supply bill) \\
\hline 24 & Environment $\log$ & $\begin{array}{l}\text { Publish environment log (regular report, edition journals of discharge, energy consumption, accident, } \\
\text { impairment) }\end{array}$ \\
\hline
\end{tabular}

Table 3. Profile of Interviewed Manufacturers

\begin{tabular}{|c|c|c|c|c|c|}
\hline Company & Founding Year & $\begin{array}{c}\text { Capital } \\
\text { (NT\$ billion) }\end{array}$ & Major Products & $\begin{array}{l}\text { Listed or } \\
\text { OTC }\end{array}$ & $\begin{array}{l}\text { Subject } \\
\text { Tittle }\end{array}$ \\
\hline A & 1952 & 2.9 & Human medicine, orthopedic appliance, animal medicine & Yes & General Manager \\
\hline B & 1967 & 1.5 & $\begin{array}{l}\text { Western medicine, Chinese traditional medicine, material medicine, animal medicine, } \\
\text { biochemical supplement }\end{array}$ & Yes & Assistant Manager \\
\hline C & 1715 & 670 & Prescription medicine, health product, oral cleaning, prepared medicine & Yes & Regional Manager \\
\hline D & 1988 & 1.1 & Western medicine, Chinese traditional medicine, health food & Yes & Regional Director \\
\hline$E$ & 1993 & 0.831 & $\begin{array}{l}\text { Various Western medicines, Western medicine material, antibiotics, serum, vaccine, } \\
\text { medical equipment }\end{array}$ & No & General Manager \\
\hline
\end{tabular}


industry. The basic data for the chosen manufacturers is shown in Table 3 . As for the indepth interviews, subjects were senior executives serving in this industry, or purchasing supervisors of companies in this industry.

The most significant problems the companies faced are the lack of standard evaluation processes and green criteria to rank suppliers. The green supplier evaluation processes are not performed systematically. The interview material also uncovered many key factors and concerns for developing such a procedure. We thus asked the experts to rate the criteria shown in Table 2. The rating scale ranged from 5 points (very important) to 1 point (not important). If the average score for a criterion was higher than 4 , then it was adopted. In total, 14 criteria were selected for further analysis. We divided the 14 criteria into five categories, namely: environmental management system, general management ability, environmental protection ability, environment improvement cost, and environmental protection related documentation.

\subsection{Step 2: Build Criterion Hierarchy}

Using multiple criteria, AHP is a simple evaluation method to determine precedence. This study used
AHP to confirm the five categories and 14 criteria (cGMP certification, environmental protection policy and objectives, executive support, environmental protection partner, product acknowledgement, usage of environmental-friendly materials, ability to decrease pollution, procurement of environmental-friendly materials, acquiring new environmental-friendly technology, product redesign, employee training cost, management of departmental documents, bill of waste management, environment log). The hierarchy structure was built and is shown in Figure 1.

\subsection{Step 3: Calculate the Weight of Each Criterion}

This step was divided into four stages: performing interviews based on the questionnaire; establishing a pairwise comparison matrix; computing criterion weights; and calculating consistency.

This study completed the AHP expert questionnaire on the basis of the above criteria. In total, ten experts were interviewed and eight questionnaires were valid, i.e. consistency index, $\mathrm{CI}<0.1$, and consistency ration, $\mathrm{CR}<0.1$. If the number of effective questionnaires had amounted

Figure 1. Criterion Hierarchy of AHP

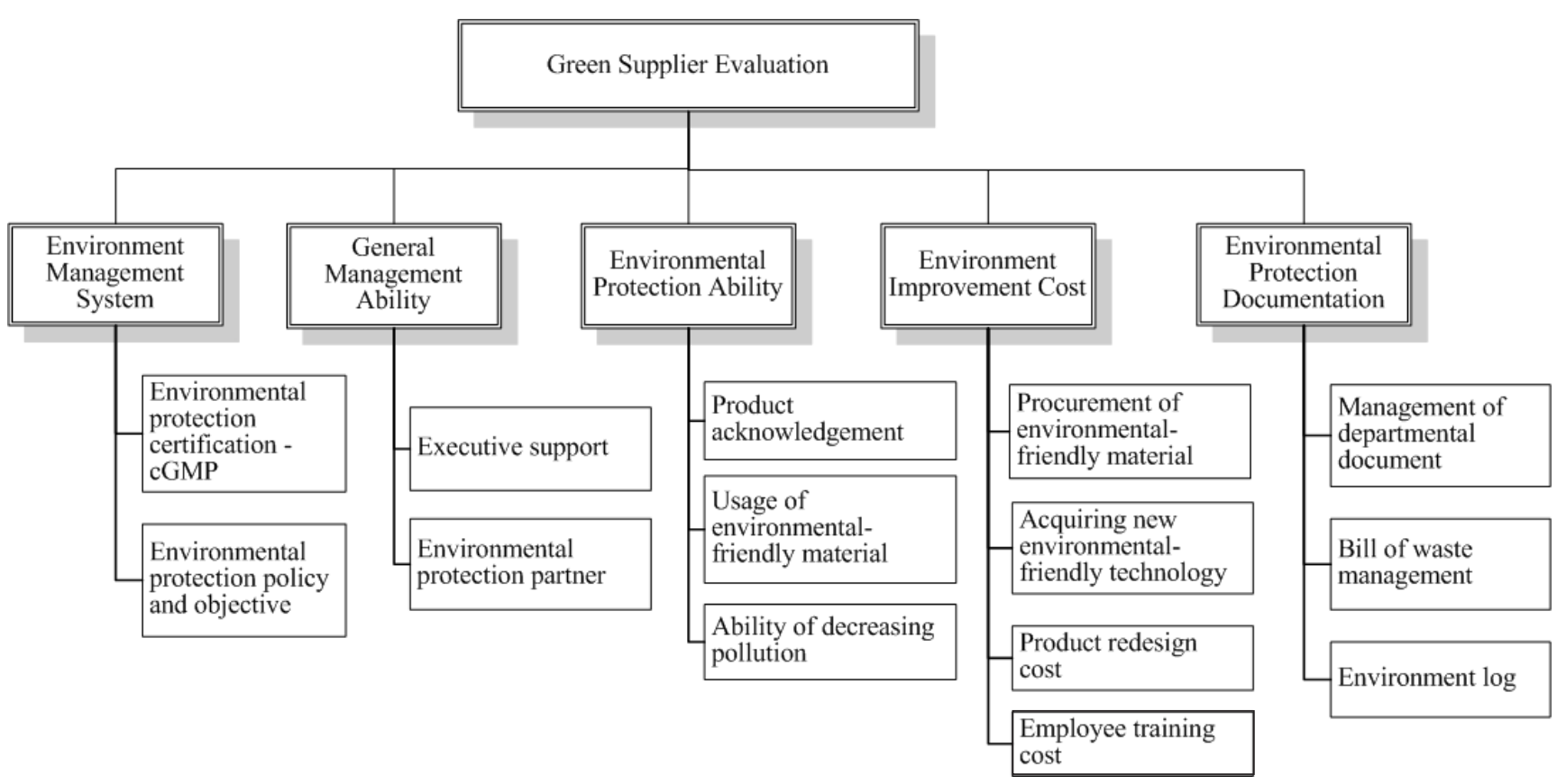


to three, it would have indicated compliance with the AHP hypothesis (Lin, 2005). The experts interviewed were primarily senior pharmacy executives with decisive power, and they were also knowledgeable regarding environment protection issues. Thus, they were able to express precise and insightful opinions.

The comparison matrix was then established. Once the pairwise comparison matrix was established, the precedence of each criterion could be calculated. After normalization process, the normalized pairwise comparison matrix can be obtained, as shown in Table 4 . The criterion score was calculated by averaging the normalized values in each row; these were in turn used to compute consistency measures and a consistency index, and finally the consistency ratio.

\subsection{Step 4: Summarize the AHP Questionnaire}

We processed the questionnaires into the pairwise comparison matrix one by one, and calculated precedence according to the above steps. Every column in Table 5 represents the weight of each criterion rated by each expert (e.g., the first expert rated environment management systems with a weight of 0.557 ); every row represents a criterion of each hierarchy in the AHP structure.

AHP uses a consistency ratio to check the pairwise comparison consistency, and if this ratio exceeds 0.1 , it indicates inconsistent judgment. In this case, the decision maker had to correct the original values of the pairwise comparison matrix. It was also necessary to check the $\mathrm{CI}$ and $\mathrm{CR}$ values - if the consistency ratio was less than 0.1 , then the pairwise comparison consistency was deemed to be a reasonable level, e.g., for the first expert, $\mathrm{CI}=0.085<0.1$, $\mathrm{CR}=0.076<0.1$.

\subsection{Compute the Average Weights}

A total of ten experts attended this questionnaire investigation. Two questionnaires with high inconsistency were omitted; hence there were eight effective questionnaires in total. Every hierarchy in each questionnaire has its own weight and consistency ratio. To integrate the questionnaire weights as given by these experts, this study calculated the weight of every criterion in all questionnaires using a weighted average. For instance, the weights of the environment management system criteria as rated by expert 1 thru expert 8 were $0.557,0.567,0.386,0.388,0.149$,

Table 4. Normalized Pairwise Matrix for Main Criterion

\begin{tabular}{|c|c|c|c|c|c|c|c|}
\hline & $\begin{array}{c}\text { Environment } \\
\text { Management } \\
\text { System }\end{array}$ & $\begin{array}{c}\text { General } \\
\text { Management } \\
\text { Ability }\end{array}$ & $\begin{array}{c}\text { Environmental } \\
\text { Protection } \\
\text { Ability }\end{array}$ & $\begin{array}{c}\text { Environment } \\
\text { Improvement } \\
\text { Cost }\end{array}$ & $\begin{array}{c}\text { Environmental } \\
\text { Protection } \\
\text { Documentation }\end{array}$ & $\begin{array}{c}\text { Criterion } \\
\text { Score }\end{array}$ & $\begin{array}{c}\text { Consistency } \\
\text { Measure }\end{array}$ \\
\hline $\begin{array}{c}\text { Environment } \\
\text { Management } \\
\text { System }\end{array}$ & 0.121951 & 0.078647 & 0.122804 & 0.241371 & 0.1851852 & 0.149992 & 9.519056 \\
\hline $\begin{array}{c}\text { General } \\
\text { Management } \\
\text { Ability }\end{array}$ & 0.609756 & 0.393236 & 0.6140243 & 0.241371 & 0.2592593 & 0.423529 & 20.230784 \\
\hline $\begin{array}{c}\text { Environmental } \\
\text { Protection } \\
\text { Ability }\end{array}$ & 0.121951 & 0.078647 & 0.1228049 & 0.241371 & 0.2592593 & 0.164807 & 14.056875 \\
\hline $\begin{array}{c}\text { Environment } \\
\text { Improvement } \\
\text { Cost }\end{array}$ & 0.121951 & 0.393236 & 0.1228049 & 0.241371 & 0.2592593 & 0.227725 & 11.830840 \\
\hline $\begin{array}{c}\text { Environmental } \\
\text { Protection } \\
\text { Documentation }\end{array}$ & 0.024390 & 0.056233 & 0.0175611 & 0.034516 & 0.0370370 & 0.033947 \\
\hline
\end{tabular}


Table 5. Weights of Criterion Categories and CR values

\begin{tabular}{|c|c|c|c|c|c|c|c|}
\hline No. & $\begin{array}{c}\text { Environment } \\
\text { Management } \\
\text { System }\end{array}$ & $\begin{array}{c}\text { General } \\
\text { Management } \\
\text { Ability }\end{array}$ & $\begin{array}{c}\text { Environmental } \\
\text { Protection } \\
\text { Ability }\end{array}$ & $\begin{array}{c}\text { Environment } \\
\text { Improvement } \\
\text { Cost }\end{array}$ & $\begin{array}{c}\text { Environmental } \\
\text { Protection } \\
\text { Documentation }\end{array}$ & Cl & CR \\
\hline 1 & 0.557 & 0.147 & 0.154 & 0.090 & 0.049 & 0.085 & 0.076 \\
2 & 0.567 & 0.161 & 0.154 & 0.075 & 0.041 & 0.083 & 0.074 \\
3 & 0.386 & 0.166 & 0.343 & 0.051 & 0.051 & 0.070 & 0.060 \\
4 & 0.388 & 0.159 & 0.338 & 0.071 & 0.042 & 0.097 & 0.086 \\
5 & 0.149 & 0.423 & 0.164 & 0.227 & 0.033 & 0.090 & 0.080 \\
6 & 0.276 & 0.155 & 0.155 & 0.184 & 0.227 & 0.090 & 0.080 \\
7 & 0.348 & 0.177 & 0.177 & 0.222 & 0.073 & 0.040 & 0.040 \\
8 & 0.557 & 0.130 & 0.130 & 0.130 & 0.051 & 0.010 & 0.010 \\
Total & 3.228 & 1.518 & 1.665 & 1.050 & 0.567 & - & - \\
Average & 0.403 & 0.189 & 0.208 & 0.131 & 0.070 & - \\
Rank & 1 & 3 & 2 & 4 & 5 & - \\
\hline
\end{tabular}

$0.276,0.348$, and 0.557 respectively. These eight weights add up to 3.228 , and the average is 0.403 . Calculation results of all weights in all categories by all experts are shown in Table 5. It was found that the criterion precedence order was "environment management systems", "environmental protection ability", "general management ability", "environmental improvement costs", and "environmental protection documentation."

\subsection{Analyze the Weight of Each Criterion}

The overall weight analysis was performed, and the results are tabulated in Table 6 . It was found that pharmaceutical manufacturers put a high priority on certification (0.611) and environment protection policies $(0.388)$, which is also why the government has played an active role in tutoring manufacturers to obtain their environmental protection certification; further, pharmaceutical manufacturers insist that environmental protection ability is more important than general management ability, because general management ability can be obtained through training and education. Pharmaceutical manufacturers that lack an ability to protect the environment face having their enterprise image hurt, which can lead to downgraded performance. Further, the environmental protection related documentation criterion was not so highly prioritized because the purchasing process focuses on suppliers' environmental protection ability instead.

It also can be seen that although the criterion weight of executive support (0.512) was greater than the weight of environmental protection partner (0.487), the difference was small. This indicates the importance of executive support in a company, as well as becoming an environmental protection partner along with a supply chain member. In this way, the general management ability of a pharmaceutical factory can be elevated, and consequently the pharmaceutical factory can respond effectively to rising environmental protection pressure, and also acquire more advantages to facilitate overall development.

The weight of product acknowledgement was 0.550, which was the most important among the three criteria in the Environment Protection Ability category. The customer impressions of the purchased product influence the overall image of the company. Therefore, experts demand that product $R \& D$, manufacturing processes, product packaging and final delivery must not threaten the environment. Once a product suggests a negative message to customers, it hampers the company image; hence experts put high emphasis on product 
acknowledgement. Pharmaceutical factory attention to using environmental-friendly materials and lowering pollution was not as relatively significant, because cGMP certification mandates manufacturers to have regulations related to environmental protection.

Furthermore, it was found that pharmaceutical factories spend considerable investment on developing/procuring new environmental-friendly technology in order to pass the cGMP certification, as medicine manufacturing may contribute to air pollution, water pollution, or solid waste pollution, all of which easily pollute the environment. New manufacturing technology can decrease the above types of pollution, so experts regard the acquisition of new environmental-friendly technology as a must. Furthermore, if products threaten the environment, then pharmaceutical factories must employ countermeasures. In reality, pharmaceutical factories list a sum of costs to deal with these products, or redesign products to meet customer and environment requirements. In this study, experts thought that if products could comply with regulations during the design process, then no additional costs would be needed. Therefore, the importance of buying environmental-friendly material was deemed not so significant due to pharmaceutical factory ecological particularities: drugs are primarily taken by humans or animals, and their necessary ingredients are produced in nature. Thus, the importance of this item was deemed to be less significant. People generally regard employee training very important, but the expert rating of this item suggests that it was not as important, probably due to the fact that companies generally conduct relevant staff environmental education training during meetings. Practically, a company would not want to incur an additional cost to train staff regarding this matter.

As to pharmaceutical factories, the primary criterion regarding environmental protection related documentation was how each department deals with the related documents (0.556), as well as how they deal with purchasing department categorized related waste or purchased green products, in terms of documenting them for supervisors or cGMP certification teams to audit. Manufacturers paid more attention to bills of waste management because related pollutants are discharged in the manufacturing process; therefore, environmental protection engineers must dispose of the waste effectively and document the process for auditing. The environment log was deemed to be less important: if pharmaceutical factories conduct obligated environmental protection practices routinely, big problems are unlikely. However, pharmaceutical factories do not publicize how to dispose of waste or document how substances threaten the environment.

After the weight analysis for each criterion category and each criterion, an overall weight for each criterion was calculated by multiplying the weight of the criterion category and the weight of each criterion. Taking cGMP certification as an example, the overall weight was calculated by multiplying the weight of the criterion category (environment management system), 0.403, by the cGMP certification weight, 0.611 , which yielded an overall weight of 0.246 . The overall weight and its rank, as shown in Table 6, represent the importance of each criterion in the whole supplier evaluation model.

In short, the top three overall weights were: cGMP certification (0.246), environmental protection policy (0.156), and product acknowledgement (0.114); the sum of these three was 0.516 , which is more than $50 \%$. As two of the three were deemed minor criteria according to the environment management system, this indicates the highlighted importance of the environment management system. In addition, if consumers have a good impression of a company after buying a product, enterprise image is further elevated, so this was deemed to be one of the key indices when evaluating green suppliers. The last three criteria were: bill of waste management (0.02), employee training costs (0.015), and environment log (0.01), two of which were in the category of environmental protection related documentation, revealing that the environmental protection documentation of upstream suppliers was less emphasized.

\subsection{Construct a Green Suppliers Evaluation Form}

Based on the evaluation criteria and their weights, a green supplier evaluation form was proposed as shown in Table 6. By rating each supplier based on the proposed criteria and weights indicated in Table 6, the 
Table 6. Green Supplier Evaluation Form

\begin{tabular}{|c|c|c|c|c|c|c|}
\hline $\begin{array}{l}\text { Main Criterion } \\
\text { (Weight) }\end{array}$ & Sub Criterion(Weight) & Rank & $\begin{array}{c}\text { Overall } \\
\text { Weight (a) }\end{array}$ & Score(b) & Weighted Score (a*b) & Sub-total \\
\hline \multirow{2}{*}{$\begin{array}{l}\text { Environment } \\
\text { Management } \\
\text { System }(0.403)\end{array}$} & Environmental protection certification - cGMP (0.611) & 1 & 0.246 & & & \\
\hline & Environmental protection policy and objective (0.388) & 2 & 0.156 & & & \\
\hline \multirow{2}{*}{$\begin{array}{l}\text { General } \\
\text { Management } \\
\text { Ability }(0.189)\end{array}$} & Executive support (0.512) & 4 & 0.097 & & & \\
\hline & Environmental protection partner $(0.487)$ & 5 & 0.092 & & & \\
\hline \multirow{3}{*}{$\begin{array}{l}\text { Environmental } \\
\text { Protection Ability } \\
(0.208)\end{array}$} & Product acknowledgement (0.550) & 3 & 0.114 & & & \\
\hline & Usage of environmental-friendly material (0.186) & 8 & 0.039 & & & \\
\hline & Ability of decreasing pollution (0.262) & 7 & 0.054 & & & \\
\hline \multirow{4}{*}{$\begin{array}{l}\text { Environment } \\
\text { Improvement } \\
\text { Cost }(0.131)\end{array}$} & Procurement of environmental-friendly material $(0.201)$ & 11 & 0.026 & & & \\
\hline & Acquiring new environmental-friendly technology $(0.441)$ & 6 & 0.058 & & & \\
\hline & Product redesign cost (0.238) & 10 & 0.031 & & & \\
\hline & Employee training cost $(0.118)$ & 13 & 0.015 & & & \\
\hline \multirow{3}{*}{$\begin{array}{l}\text { Environmental } \\
\text { Protection } \\
\text { Documentation } \\
(0.070)\end{array}$} & Management of departmental document (0.556) & 8 & 0.039 & & & \\
\hline & Bill of waste management $(0.291)$ & 12 & 0.020 & & & \\
\hline & Environment log $(0.148)$ & 14 & 0.010 & & & \\
\hline \multicolumn{7}{|c|}{ SUM = } \\
\hline $\begin{array}{l}\square \text { A. Excellent } \\
\square \text { B. Very Good } \\
\square \text { C. Good } \\
\square \text { D. Fair } \\
\square \text { E. Fail }\end{array}$ & $\begin{array}{l}(90 \leq S U M \leq 100) \\
(80 \leq S U M<90) \\
(70 \leq S U M<80) \\
(60 \leq S U M<70) \\
(0 \leq S U M<60)\end{array}$ & $\begin{array}{l}\text { Final } \\
\square \text { Re } \\
\square \text { Re } \\
\square \text { Av }\end{array}$ & $\begin{array}{l}\text { ision: } \\
\text { dy for Placing } 0 \\
\text { evaluation Need } \\
\text { id Placing Order }\end{array}$ & $\begin{array}{l}\text { der }(A, B) \\
\text { d after Improv } \\
\text { F) }\end{array}$ & ment (C,D) & \\
\hline
\end{tabular}

suppliers can be effectively evaluated. The supplier evaluation results were divided into groups A, B, C, D and $\mathrm{E}$, according to the summary of weighted scores. Thus, the final decision of whether or not to place an order can be made according to the supplier level: (1) A or B: adequate to place orders, (2) C or D: hold until the supplier makes improvements on environmental protection issues, and (3) E: avoid placing orders.

\section{Conclusions}

The biotechnology industry is generally regarded as one of the most prospective star industries in the $21^{\text {st }}$ century, and is involved in several key promotion projects in Taiwan, such as "Challenge 2008-National Key Development Program" and "Two-Trillion-Twin-Stars". Environmental protection has gradually become a noticeable issue for manufacturers in new product $R \& D$; therefore, supporting one's company with the technology needed to develop a green supply chain is now a crucial part of enhancing industry competence.

Different enterprises might be located at different levels of the supply chain, and views of one supplier are likely to differ. Therefore, the evaluation model and criteria proposed in this study apply to green supplier evaluation in the biotechnology industry, and can assist firms in their desire to facilitate an overall supply chain operation that complies with environmental protection requirements. In terms of current supplier evaluations, the major focuses of an enterprise remain on the traditional criteria, but in light of rising environmental protection awareness, environmental protection related concepts must be added to supplier evaluations. 
Based on the related literature, this study proposed green criteria needed for a green supplier evaluation process, and used practical interviews to analyze how manufacturers conduct green supplier evaluations, so as to build a better green evaluation criterion structure and supplier evaluation process. This study employed the Analytic Hierarchy Process as supplier evaluation method, and calculated relative weights to obtain quantifiable criteria for rating qualified suppliers.

The results are summarized as: (1) the way pharmaceutical factories currently evaluate green suppliers is mainly based on checking whether or not the supplier has passed the cGMP certification, it has established environmental protection policies, and it has product acknowledgements. (2) Based on the expert interviews and literature analysis, this study provides several criteria for biotechnology manufacturers to use when evaluating green suppliers. (3) A model was constructed that details the process of evaluating upstream green suppliers for biotechnology manufacturers. Based on the evaluation criteria and the procedures provided in this study, relative weights for the criteria were calculated, and a green supplier evaluation form was proposed, which can help decision makers to evaluate green suppliers in a more systematic manner.

\section{Acknowledgement}

The authors would like to thank the National Science Council, Taiwan, for financially supporting this research under Contract No. NSC94-2213-E167-006.

\section{References}

Alshuwaikhat, H.M. (2005). Strategic environmental assessment can help solve environmental impact assessment Failures in Developing Countries. Environmental Impact Assessment Review 25, pp.307-317.

Barbarosoglu, G. and Yazgac, T. (1997). An application of the analytic hierarchy process to the supplier selection problem. Production and Inventory Management Journal 38(1), pp.14-21.

Beamon, B.M. (1999). Designing the green supply chain. Logistics Information Management 12(4), pp.332-342.

Bharadwaj, N. (2004). Investigating the decision criteria used in electronic components procurement. Industrial Marketing Management 33, pp.317-323.
Bhutta, K.S. (2002). Supplier selection problem: a comparison of the total cost of ownership and analytic hierarchy process approaches. Supply Chain Management 7(3/4), p.126, ABI/INFORM Global.

Blenkhorn, D.L. and Noori, A.H. (1991). What it takes to supply Japanese OEMs. Industrial Marketing Management 19 (1), pp. 21-30.

Buckley, J.J. (1985). Fuzzy hierarchical analysis. Fuzzy Sets and Systems 17, pp.343-350.

Chen, Y.-X. and Chen, M.-Z. (2001). Strategies for supply chain management and global logistics competition. Proceedings of Technology and Management Conference, Taipei, Taiwan, pp. 47-54.

Chien, Z.-J. (2000). Constructing a supplier evaluation model with strategic partner relationship with analytic hierarchy process, unpublished Master's Thesis, Fu-Jen Catholic University, Taiwan (in Chinese).

Crama, Y. (2004). Optimal procurement decisions in the presence of total quantity discounts and alternative product recipes. European Journal of Operational Research 159, pp.364-378.

Degraeve, Z. (2000). An evaluation of vendor selection models from a total cost of ownership perspective. European Journal of Operational Research 125, pp.34-58.

Ellram, L.M. (1995). Total cost of ownership: An analysis approach for purchasing. International Journal of Physical Distribution and Logistics Management 25(8), pp.4-23.

Fu, Y.H. (2004). Supply-side collaboration and its value in supply chains. European Journal of Operational Research 152, pp.281-288.

Geier, U. and Kopke, U. (1998). Comparison of conventional and organic farming by process life cycle assessment: a case study of agriculture in Hamburg. Proceedings of the International Conference on Life Cycle Assessment in Agriculture, Agroindustry and Forestry, Brussels, Belgium, pp. 31-38.

Ghodsypour, S.H. (1998). A decision support system for supplier selection using an integrated analytic hierarchy process and linear programming. International Journal of Production Economics 56/57, pp.199-212.

Goffin, K., Szwejczewski, M. and New, C. (1997). Managing suppliers: when fewer can mean more. International Journal of Physical Distribution and Logistics Management 27(7), pp.422-436.

Gregory, R.E. (1986). Source selection: A matrix approach. Journal of Purchasing and Materials Management 22(2), pp.24-29.

Handfield, R., Walton, S.V., Sroufe, R. and Melnyk, S.A. (2002). Applying environmental criteria to supplier assessment: a study in the application of the analytical hierarchy process. European Journal of Operational Research 141, pp.70-87.

Hinkle, C.L., Robinson, P.J. and Green, P.E. (1969). Vendor evaluation using group analysis. Journal of Purchasing (August), pp. 49-58. 
Humphreys, P.M. and Chan, R.F. (2003). Using case-based reasoning to evaluate supplier environmental management performance. Expert Systems with Applications 25, pp.141153.

Humphreysa, P.K., Wong, Y.K. and Chan, F.T.S. (2003). Integrating environmental criteria into the supplier selection process. Journal of Materials Processing Technology 138, pp.349-356.

IDB/MOEA (Industrial Development Bureau, Ministry of Economic Affairs), www.moeaidb.gov.tw, Access 2006/ $05 / 20$.

Ju, S.-Y. (2004). Constructing an advanced planning and scheduling system for supply chain management - from the perspective of order discrepancy. Unpublished Master's Thesis, Department of Industrial Management, National Ping-Tung University of Science and Technology (in Chinese).

Juang, Y.-S., Kao, H.-P., Lin, S.-S. and Cheng, Y.-L. (2006). A simulation approach to collaborative supply chain design. ACME Transactions 2006 (Proceedings of the 16th International Conference on Pacific Rim Management, Association for Chinese Management Educators 2006 Annual Meeting, C4503), Honolulu, Hawaii, 7/27-29, pp.564-569.

Kumar, M. (2004). A fuzzy goal programming approach for vendor selection problem in a supply chain. Computers and Industrial Engineering 46, pp.69-85.

Kuo, T.-C., Liao, Y.-J. and Chio, J.-X. (2004). Construction and analysis of a green supply chain management system in re-production environment. Proceedings of the 2004 Annual Conference of Chinese Institute of Industrial Engineers. Tainan, Taiwan, Dec. 18 (in Chinese).

Lai, Y.-F. (2004). Green supplier evaluation in green supply chain management - examples of printed circuit board suppliers. unpublished Master's Thesis, Department of Resource Engineering, National Cheng-Kung University, Taiwan (in Chinese).

Lamberson, L.R., Diederich, D. and Wuori, J. (1976). Quantitative vendor evaluation. Journal of Purchasing and Materials Management (Spring), pp.19-28.

Lee, H.-W. (2002). A Supplier Evaluation Model Combining analytic hierarchy process, Fuzzy Theory and Grey System. Department of Production System Engineering and Management, National Taipei University of Science and Technology, Taiwan (in Chinese).

Lee, W.-D. (2006). The status quo of waste treatment and reuse in Taiwanese biotechnology industry- Series I and II, wec.itri.org.tw/ping/ e-paper/news18/pdf/projectVOL18.pdf. Access on 2006/04/11.

Lin, W.-T., Lo, K.-C. and Kuo, C.-L. (2002). The research on the uncertainty factors and the adaptive strategies for the implementation of supply chain management - using information and electronic industry in Taiwan as the study object. Journal of the Chinese Institute of Industrial Engineers 19(6), pp.60-78.

Liu, F.-H. and Hai, H.L. (2005). The voting analytic hierarchy process method for selecting supplier. International Journal of Production Economics 97, pp.308-317.
Mandal, A. and Deshmukh, S.G. (1994). Vendor selection using interpretative structural modeling (ISM). International Journal of Operations and Production Management 14(6), pp.52-59.

McCutcheon, D.M., Grant, R.A. and Hartley, J. (1997). Determinants of new product designer's satisfaction with suppliers' contributions. Journal of Engineering and Technology Management 14, pp.273-290.

MOEA (Ministry of Economic Affairs) (2002), 2002 White Book of Biotechnology Industry in Taiwan. Retrieved Oct. 14, 2005, from http://www.biopharm.org.tw/download/ pdf/white_page_2002.pdf.

MOEA (Ministry of Economic Affairs), Retrieved May 20, 2006, from http://www.moea.gov.tw

Mohanty, R.P. and Deshmukh, S.G. (1993). Use of analytic hierarchic process for evaluating sources of supply. International Journal of Physical Distribution and Logistics Management 23(3), pp.22-38.

Mummalaneni, V., Dubas, K.M. and Chao, C. (1996). Chinese purchasing managers' preferences and trade-offs in supplier selection and performance evaluation. Industrial Marketing Management 25(2), pp.115-124.

Muralidharan, C. (2001). Vendor rating in purchasing scenario: a confidence interval approach. International Journal of Operations and Production Management 21, p.1305, ABI/INFORM Global.

Muralidharan, C. (2002). A multi-criteria group decisionmaking model for supplier rating. Journal of Supply Chain Management 38(4), p.22, ABI/INFORM Global.

Nagel, M.H. (2000). Environmental supply-chain management versus green procurement in the scope of a business and leadership perspective. LG Journal of Production Engineering 3(7).

Naisbitt, J. and Aburdene, P. (1990). Megatrends 2000. New York: William Morrow and Company, Inc.

Narasimhan, R. (1983). An analytical approach to supplier selection. Journal of Purchasing and Materials Management 19(4), pp.27-32.

Narasimhan, R. (2001). Supplier evaluation and rationalization via data envelopment analysis: An empirical examination. Journal of Supply Chain Management 37(3), p.28, ABI/INFORM Global.

Newman, R.G. (1989). Single sourcing: short-term savings versus long-term problems. International Journal of Purchasing and Materials Management 25, pp.20-25.

Noci, G. (1997). Designing green vendor rating systems for the assessment of a supplier's environmental performance. European Journal of Purchasing and Supply Management 3(2), pp.103-114.

Nydick, R.L. and Hill, R.P. (1992). Using the analytic hierarchy process to structure the supplier selection procedure. International Journal of Purchasing and Materials Management 28(2), pp.31-36.

Pan, A.C. (1989). Allocation of order quantity among suppliers. Journal of Purchasing and Materials Management 25, pp.36-39. 
Patton, W.W. (1996). Use of human judgment models in industrial buyer's vendor selection decisions. Industrial Marketing Management 25, pp.135-149.

Petroni, A. and Braglia, M. (2000). Vendor selection using principal component analysis. Journal of Supply Chain Management 36(2), pp.63-69.

Prahinski, C. (2004). Supplier evaluations communication strategies to improve supplier performance. Journal of Operations Management 22, pp.39-62.

Pun, K.F.I, Hui, I.K., Lewis, W.G. and Lau, H.C.W. (2003). A multiple-criteria environmental impact assessment for the plastic injection molding process. Journal of Cleaner Production 11, pp.41-49.

Rifkin, J. (1999). The Biotech Century: Harnessing the Gene and Remarking the World. Putnam: Jeremy P. Tarcher.

Rodrigues, G.S., Campanhola, C. and Kitamura, P.C. (2003). An environmental impact assessment system for agricultural R\&D. Environmental Impact Assessment Review 23(2), pp.219-244.

Ross, A. and Droge, C. (2001). An integrated benchmarking approach to distribution center performance using DEA modeling. Journal of Operations Management 20, pp.1932.

Rubin, P.A. and Carter, J.R. (1990). Joint optimality in buyerseller negotiations. International Journal of Purchasing and Materials Management 26, pp.20-26.

Saaty, T.L. (1980). The Analytic Hierarchy Process, New York: McGraw-Hill.

Sarkis, J. (2002). A model for strategic supplier selection. Journal of Supply Chain Management 38(1), p.18, ABI/ INFORM Global.

Scharnhorst, W., Althaus, H.J., Classen, M., Jolliet, O. and Hilty, L.M. (2005). The end of life treatment of second generation mobile phone networks: Strategies to reduce the environmental impact. Environmental Impact Assessment Review 25, pp.540-566.

Shief, M.-H. (2006). Constructing and analyzing green supplier selection models for biotechnology industry, unpublished Master's Thesis, Department of Business Administration, National Chin-Yi University of Technology, Taiwan (in Chinese).

Siying, W., Jinlong, Z. and Zhicheng, L. (1997). A supplier selecting system using a neural network. Proceedings of IEEE International Conference on Intelligent Processing Systems, IEEE, New York, pp. 468-471.

Small-and-Medium Enterprise Affairs, MOEA, 2002 White book of small-and-medium sized enterprises. Retrieved June 11, 2006 from http://www.moeasmea.gov.tw/ Data_Service/95white/white95.asp

Spekman, R.E. (1998). Perceptions of strategic vulnerability among industrial buyers and its effect on information search and supplier evaluation. Journal of Business Research 17, pp.313-326.
Stuart, F.I. and McCutcheon, D. (1995). Problem sources in establishing strategic supplier alliances. International Journal of Purchasing and Materials Management, 31: 39.

Su, Y.-J. and Zhang, S.-H. (2001). Application of extenics system on supplier evaluation model. Proceedings of the 2001 Annual Conference of Chinese Institute of Industrial Engineers. Tainan, Taiwan, Dec. 8 (in Chinese).

Talluri, S., Narasimhan, R. and Nair, A. (2005). Vendor performance with supply risk: A chance-constrained DEA approach. International Journal of Production Economics 100, pp.212-222.

Timmerman, E. (1986). An approach to vendor performance evaluation. Journal of Purchasing and Materials Management 22(4), pp.2-8.

Tsai, S.-F. (2005). A study on green supplier evaluation model - An example of integrated circuit packaging industry. unpublished Master's Thesis, Department of Business Administration, National Sun Yat-Sen University, Taiwan (in Chinese).

Turner, I. (1988). An independent system for the evaluation of contract tenders. Journal of Operational Research Society 39(6), pp.551-561.

Walton, S.V., Handfield, R.B. and Melnyk, S.A. (1998). The green supply chain: Integrating suppliers into environmental management processes. International Journal of Purchasing and Materials Management 34(2), pp.2-11.

Wang, G. (2004). Product-driven supply chain selection using integrated multi-criteria decision-making methodology. International Journal of Production Economics 91, pp.115.

Webb, L. (1994). Green purchasing: forging a new link in the supply chain. American Society of Agricultural Engineers 1(6), pp.14-18.

Weber, C.A (1998). Non-cooperative negotiation strategies for vendor selection. European Journal of Operational Research 108, pp.208-223.

Weber, C.A. and Desai, A. (1996). Determinants of paths to vendor market efficiency using parallel coordinates representation: A negotiation tool for buyers. European Journal of Operational Research 90, pp.142-155.

Wind, Y. and Robinson, P.J. (1968). The determinants of vendor selection: The evaluation function approach. Journal of Purchasing and Materials Management (August), pp.29-41.

Zhang, J.-Y. (2005). A Study on green supply strategy in the soft printed circuit board industry, Fareast Journal, 22(6), pp.169-178 (in Chinese). 
Shui-Shun Lin is associate professor at the Department of Business Administration of National Chin-Yi University of Technology, Taiwan. He received his Master of Science degree from the University of WisconsinMadison, and $\mathrm{PhD}$ degree in Industrial Engineering from the Florida State University, USA. His current research interests include Sustainability Management, Decision Support System, and Knowledge Management.

Ying-Shen Juang is associate professor at the Department of Business Administration of Chung-Hua University, Taiwan. She received her PhD degree in Industrial Management from National Central University, Taiwan. Her research interests include Marketing Management, Supply Chain Management, and Customer Relationship Management. 